\title{
NIAT PERILAKU MENGGUNAKAN APLIKASI KESEHATAN GRAB HEALTH SELAMA MASA PANDEMIK COVID-19
}

\author{
Maria Lusia Viany Noel ${ }^{1}$ \\ Universitas Setia Budi Surakarta \\ (lusianoel983@gmail.com) \\ Didik Setyawan ${ }^{2}$ \\ Universitas Setia Budi Surakarta \\ (didiksetyawan1977@gmail.com) \\ Nang Among Budiadi ${ }^{3}$ \\ Universitas Setia Budi Surakarta \\ (nangamongbudiadi@gmail.com)
}

\begin{abstract}
This research aims to examine the effect of behavioural intention using the Grab Health application during the Covid-19 pandemic. Variables that support the formation of behavioral intentions are attitudes. The formation of attitudes in use is caused by perceived enjoyment, social influence, and perceived vulnerability in using Grab Health applications. Data was obtained from questionnaires were distributed to the general public who use health applications Grab Health. The sampling technique used is non probability sampling, that is convenience sampling technique. The sample used in the study was 200 respondents who used the health applications Grab Health. Hypothesis testing is done by the Structural Equation Modeling (SEM) analysis method using the AMOS program. The results of this research indicate that attitudes have a significant effect on behavioral intentions, positive perceptions of perceived enjoyment are significant to attitudes, social influences have a significant influence on attitudes, and perceptions of vulnerability do not significantly influence attitudes in the use of health applications Grab Health.
\end{abstract}

Keywords: Behavioral Intentions, Attitudes, Perceived Enjoyment, Social Influences, Perceived Vulnerability.

\section{A. PENDAHULUAN}

Kajian tentang penggunaan layanan kesehatan online penting untuk dilakukan. Hal ini dikarenakan timbulnya kewaspadaan terhadap Virus Corona (Covid-19) sehingga masyarakat dihimbau untuk tetap berada dirumah saja dan menjaga jarak dengan orang lain (detiknews, 2020). Selain itu, timbulnya keengganan masyarakat untuk pergi ke rumah sakit atau klinik karena takut akan terinfeksi Covid-19 (tribunnews.com,
2020). Berbagai permasalahan yang timbul, layanan kesehatan online yang diinovasikan untuk membantu masyarakat salah satunya Grab Health Powered by Good Doctor. Selama masa pandemi Covid-19 trafik pengguna Grab Health naik 20 kali lipat dan sebanyak 400 persen permintaan tanya jawab terkait isu-isu tentang Covid-19 (Grab.com, 2019). Maka studi ini mengkaji tentang keefektivan penggunaan layanan 
kesehatan online di masyarakat yang diukur dengan niat perilaku menggunakan.

Studi terdahulu juga masih ditemukan kesenjangan hasil pengaruh sosial terhadap niat berperilaku dalam menggunakan sistem informasi pada berbagai objek penelitian (Alshehri et al., 2012; Hossain et al., 2019). Studi yang dilakukan Alshehri et al. (2012) menemukan bahwa pengaruh sosial tidak berpengaruh signifikan terhadap niat perilaku menggunakan system informasi. Studi lain yang dilakukan Hossain et al. (2019) menemukan pengaruh sosial berpengaruh signifikan terhadap niat untuk untuk menggunakan suatu aplikasi online. Berdasarkan perbedaan hasil tersebut mengindikasikan belum bakunya hubungan antara pengaruh sosial dengan niat untuk beperilaku. Maka studi ini melakukan konfirmasi kembali hubungan kedua variabel pada objek yang berbeda.

Studi ini melakukan modifikasi model penelitian untuk membentuk niat perilaku dipengaruhi oleh empat variable independent terdiri dari kenyamanan persepsian, pengaruh sosial, dan kerentanan persepsian (Praveena dan Thomas, 2014; Rana et al., 2017; Zhao et al., 2018) dan menambahkan variabel sikap sebagai pemediasi untuk membentuk niat perilaku (Rana et al., 2015; Hamari dan Koivisto, 2017). Sikap sebagai bentuk evaluasi individu sebelum atau sesudah menggunakan suatu aplikais sistem informasi.

\section{B. TELAAH LITERATUR}

\section{Niat Perilaku}

Konsep dasar niat didefinisikan sebagai kecenderungan individu berdasarkan penilaiannya untuk melakukan suatu perilaku tertentu (Mobley et al., 1978). Berdasarkan konsep tersebut niat dimaknai sebagai persepsi individu untuk melakukan suatu perilaku berdasarkan keinginan individu itu sendiri. Konsep niat juga mengalami perubahan makna dalam penggunaan sistem informasi. Niat perilaku didefinisikan sebagai tindakan secara langsung dari perilaku individu yang memberi indikasi tentang kesiapan melakukan tindakan untuk menggunakan suatu sistem (Tharhini et al., 2015).

Studi terdahulu tentang niat perilaku menggunakan sistem informasi yang dipengaruhi oleh berbagai variabel pada berbagai objek penelitian antara lain kemudahan penggunaan dan motivasi hedonik (Serenko dan Turel, 2015; Boonsiritomachai dan Pitchayadejanat., 2017). Namun studi ini melakukan konfirmasi variable-variabel pembentukan niat perilaku menggunakan sistem informasi dipengaruhi oleh sikap, kenyamanan persepsian, pengaruh social, dan kerentanan persepsian (Kuo dan Yen., 2009; Praveena dan Thomas., 2014; Rana et al., 2017, 2017; Zhao et al., 2018).

\section{Sikap}


Jurnal Bisnis dan Kewirausahaan

Konsep dasar sikap didefinsikan sebagai perasaan positif atau negatif yang timbul dari pengalaman dan memberikan dampak pada respon individu terhadap lingkungannya (Liaw dan Huang, 2003). Sikap yang dikonsepkan sebagai perasaan kesukaan atau ketidaksukaan individu terhadap suatu objek yang mengarah pada perilaku (Lam et al., 2007). Berdasarkan pernyataan tersebut, sikap dalam penerapan aplikasi online didefinisikan sebagai sebagai penilaian individu terhadap keinginan untuk menggunakan aplikasi tersebut.

Beragam studi terdahulu yang menjelaskan adanya hubungan positif pengaruh sikap dan niat perilaku penggunaan sistem informasi (Lin et al., 2011; Nasri dan Charfeddine, 2012; Rana et al., 2015). Dalam penerapan sistem eDistrict dimana sikap memiliki efek langsung pada niat perilaku. Sikap mempunyai peran sentral dalam individu yang menggunakan sistem e-District (Rana et al., 2015). Tingginya sikap sebagai bentuk evaluasi individu terhadap objek memberikan dampak pada peningkatan niat menggunakan aplikasi kesehatan online.

\section{H1: sikap berpengaruh positif pada niat perilaku untuk menggunakan aplikasi kesehatan Grab Health.}

\section{Kenyamanan Persepsian}

Konsep dasar kenyamanan didefinisikan sebagai efek positif dari suatu proses yang dirasakan individu disebabkan
Vol-13/No-2/Oktober/2020

oleh faktor ekstrinsik dan intrinsik (Scanlan dan Lewthwaite., 1986). Kenyamanan persepsian menggunakan teknologi dijelaskan sebagai sejauh mana aktivitas menggunakan sistem tertentu dianggap menyenangkan dalam dirinya sendiri, selain dari konsekuensi kinerja yang dihasilkan dari penggunaan system (Venkatesh, 2000). Maka didasarkan dari review definisi yang sudah dijelaskan dari studi sebelumnya, maka studi ini mengajukan definisi kenyamanan persepsian sebagai keyakinan individu dalam menggunakan sistem informasi memberikan keleluasan dan kesenangan serta lebih efektif dalam penggunaannya.

Kenyamanan persepsian dapat memengaruhi niat perilaku individu secara langsung atau melalui mediasi sikap individu, dimana individu dapat mengekspresikan dirinya sesuai dengan keinginannya (Choi dan Kim, 2016). kenyamanan persepsian sebagai motivasi mendasar membentuk sikap para siswa menggunakan aplikasi online untuk bahasa pemograman (Cabada et al., 2017). Hal ini mengindikasikan bahwa niat perilaku individu untuk menggunakan suatu aplikasi online dipengaruhi oleh tingkat kenyamanan yang dirasakan.

H2: kenyamanan persepsian berpengaruh positif pada sikap untuk menggunakan aplikasi kesehatan Grab Health.

\section{Pengaruh Sosial}


Jurnal Bisnis dan Kewirausahaan

Pengaruh social didefinisikan sebagai fungsi untuk mengukur perilaku individu yang di pengaruhi oleh individu lain (Zhang et al., 2013; Chatrine et al., 2017). pengaruh sosial dalam konteks penggunaan sistem informasi adalah dimana individu memandang bahwa individu lain dapat mempercayai penggunaan teknologi tertentu (Venkatesh et al., 2012). pengaruh sosial dimaknai sebagai kepercayaan pengguna bahwa teman, kolega dan individu lain ingin terus percaya dan menggunakan aplikasi online (Chang et al., 2017). Maka dapat disimpulkan pengaruh sosial sebagai suatu persepsi individu yang mengutamakan kepercyaan dan pandangan dari individu lain untuk menggunakan dan menerapkan sistem informasi.

pengaruh sosial dari orang-orang terdekat seperti anggota keluarga, rekan kerja, dan kolega berpengaruh positif terhadap sikap karena individu akan memperbaiki sikap berdasarkan pengalaman individu lain yang sudah menggunakan sistem informasi (Yusliza dan Ramayah, 2012; Rana et al., 2016, Minha et al., 2018). Pengaruh persepsi individu terhadap individu lain dalam praktik penggunaan system informasi akan memengaruhi sikap para profesional teknologi informasi, terutama ketika individu lain menganggapnya sebagai pengguna (Ojo et al., 2019). Tingginya pengaruh dari orang-orang terdekat yang memiliki pengalaman positif memengaruhi sikap individu.
Vol-13/No-2/Oktober/2020

\section{H3: pengaruh sosial berpengaruh positif pada sikap individu untuk menggunakan aplikasi kesehatan Grab Health.}

\section{Kerentanan Persepsian}

Konsep dasar kerentanan didefinisikan sebagai dapat disimpulkan kerentanan persepsisan sebagai keadaan dimana indvidu akan merasa terancam dikarenakan peristiwa yang berdampak negatif dalam pekerjaan dan kesejahteraannya (Adger dan Kelly, 1999; Johnston dan Warkentin, 2010; Siponen et al., 2014). Kerentanan persepsian terhadap risiko privasi penggunaan sistem informasi dimaknai sebagai tingkat di mana individu pengguna aplikasi percaya bahwa ancaman privasi akan terjadi padanya (Mohamed dan Ahmad, 2012; Ifendo, 2012). Berdasarkan konsep studi terdahulu, kerentanan persepsian didefinisikan sebagai penilain individu terhadap peluang terjadinya ancaman pivasi atau virus dalam penggunaan sistem informasi.

Tingginya kerentanan persepsian seperti masalah pelanggaran privasi pengguna internet akan berdampak pada sikap individu untuk tidak mempublikasikan informasi pribadi ke internet (Salleh et al., 2012). Kerentanan persepsian secara signifikan memengaruhi sikap individu yang cenderung berkurang dalam menggunakan aplikasi kesehatn karena kerugian yang dirasakan tinggi (Guo et al., 2015). Individu 
yang memiliki persepsi kerentanan yang tinggi, akan berdampak pada rendahnya sikap menggunakan aplikasi online.
H4: kerentanan persepsian berpengaruh positif pada sikap untuk menggunakan aplikasi kesehatan Grab Health

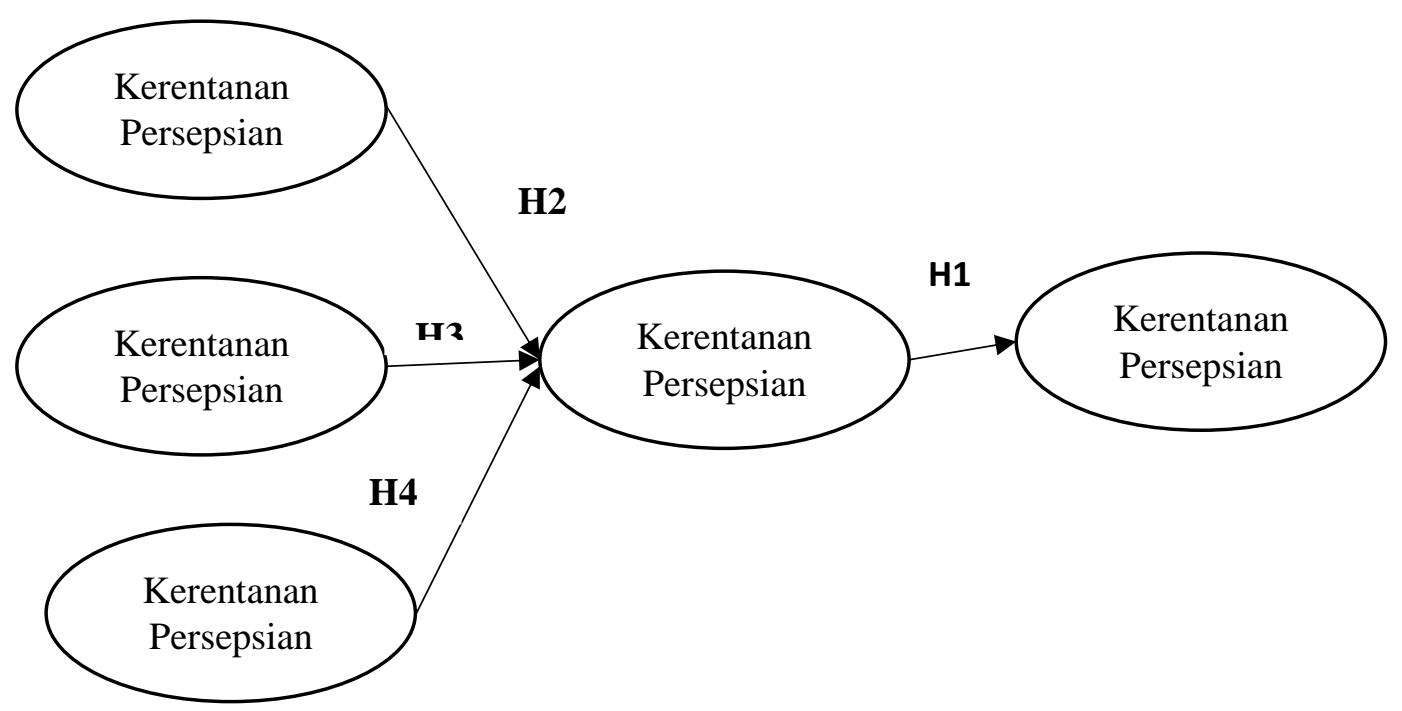

Gambar 1. Model Penelitian

\section{METODE PENELITIAN}

Studi penelitian ini merupakan penelitian causal dengan menggunakan data cross sectional. Desain pengambilan data menggunakan teknik survei dalam bentuk kuesioner. Pengambilan sampel dalam penelitian ini menggunakan teknik non probability sampling yang salah satunya adalah teknik convenience sampling. Sampel penelitian ini adalah 200 masyarakat umum yang menggunakan layanan aplikasi kesehatan Grab Health. Responden adalah masyarakat yang sudah menggunakan layanan aplikasi kesehatan Grab Health. Pengujian alat ukur menggunakan SPSS. Pengujian Hipotesis menggunakan Analisis Structural Equatio Model (SEM) dengan Program AMOS.

\section{PENGUJIAN ALAT UKUR}

Berdasarkan Tabel 1 menunjukan 20 item kuesioner yang digunakan dalam penelitian valid, dengan nilai factor loading lebih besar dari 0,40. 


\begin{tabular}{ccc}
\hline Indicator & Loading Factor & Keterangan \\
\hline NP1 & 0,771 & Valid \\
NP2 & 0,715 & Valid \\
NP3 & 0,751 & Valid \\
S1 & 0,754 & Valid \\
S2 & 0,635 & Valid \\
S3 & 0,781 & Valid \\
S4 & 0,850 & Valid \\
KP1 & 0,816 & Valid \\
KP2 & 0,938 & Valid \\
KP3 & 0,702 & Valid \\
KP4 & 0,842 & Valid \\
PS1 & 0,920 & Valid \\
PS2 & 0.957 & Valid \\
PS3 & 0,814 & Valid \\
PS4 & 0,655 & Valid \\
PK1 & 0,891 & Valid \\
PK2 & 0,919 & Valid \\
PK3 & 0,829 & Valid \\
PK4 & 0,829 & Valid \\
PK5 & 0,942 & Valid \\
\hline
\end{tabular}

Tabel 1. Hasil Uji Validitas

Berdasarkan Tabel 2. Hasil uji realibilitas kuesioner yang digunakan reliabel karena kuesioner menunjukan bahwa item-item memiliki koefisien alpha lebih besar dari 0,60.

\begin{tabular}{lcc}
\hline \multicolumn{1}{c}{ Variabel } & $\begin{array}{c}\text { Koefisien Alpha } \\
(\mathbf{\alpha})\end{array}$ & Keterangan \\
\hline Niat Perilaku (NP) & 0,758 & Reliabel \\
Sikap (S) & 0,895 & Reliabel \\
Kenyamanan Persepsian (KP) & 0,882 & Reliabel \\
Pengaruh Sosial (PS) & 0,900 & Reliabel \\
Kerentanan Persepsian (PK) & 0,929 & Reliabel \\
\hline
\end{tabular}

Tabel 2. Hasil Uji Realibilitas

\section{HASIL ANALISIS}

Uji hipotesis untuk menganalisis hubungan kasualitas variable-variabel terhadap model penelitian dengan melihat nilai crtical ratio (c.r). jika nilai c.r memenuhi syarat yang mendukung arah hubungan hipotesis maka disimpulkan hipotesis terdukung. Analisis pengujian hipotesis terlihat pada gambar 2 dan table 3 .

\begin{tabular}{ccccc}
\hline Hipotesis & Standar Estimate & c.r & Probabilitas & Keterangan \\
\hline $\mathrm{S} \rightarrow \mathrm{NP}$ & 0,107 & 8,023 & ${ }^{* * *}$ & H1 Terdukung \\
$\mathrm{KP} \rightarrow \mathrm{S}$ & 0,072 & 7,552 & ${ }^{* * *}$ & H2 Terdukung \\
$\mathrm{PS} \rightarrow \mathrm{S}$ & 0,049 & 6,421 & ${ }^{* * *}$ & H3 Terdukung \\
$\mathrm{PK} \rightarrow \mathrm{S}$ & 0,023 & $-0,445$ & 0,656 & H4 Tidak Terdukung \\
\hline
\end{tabular}

Tabel 3. Hasil Uji Hipotesis 


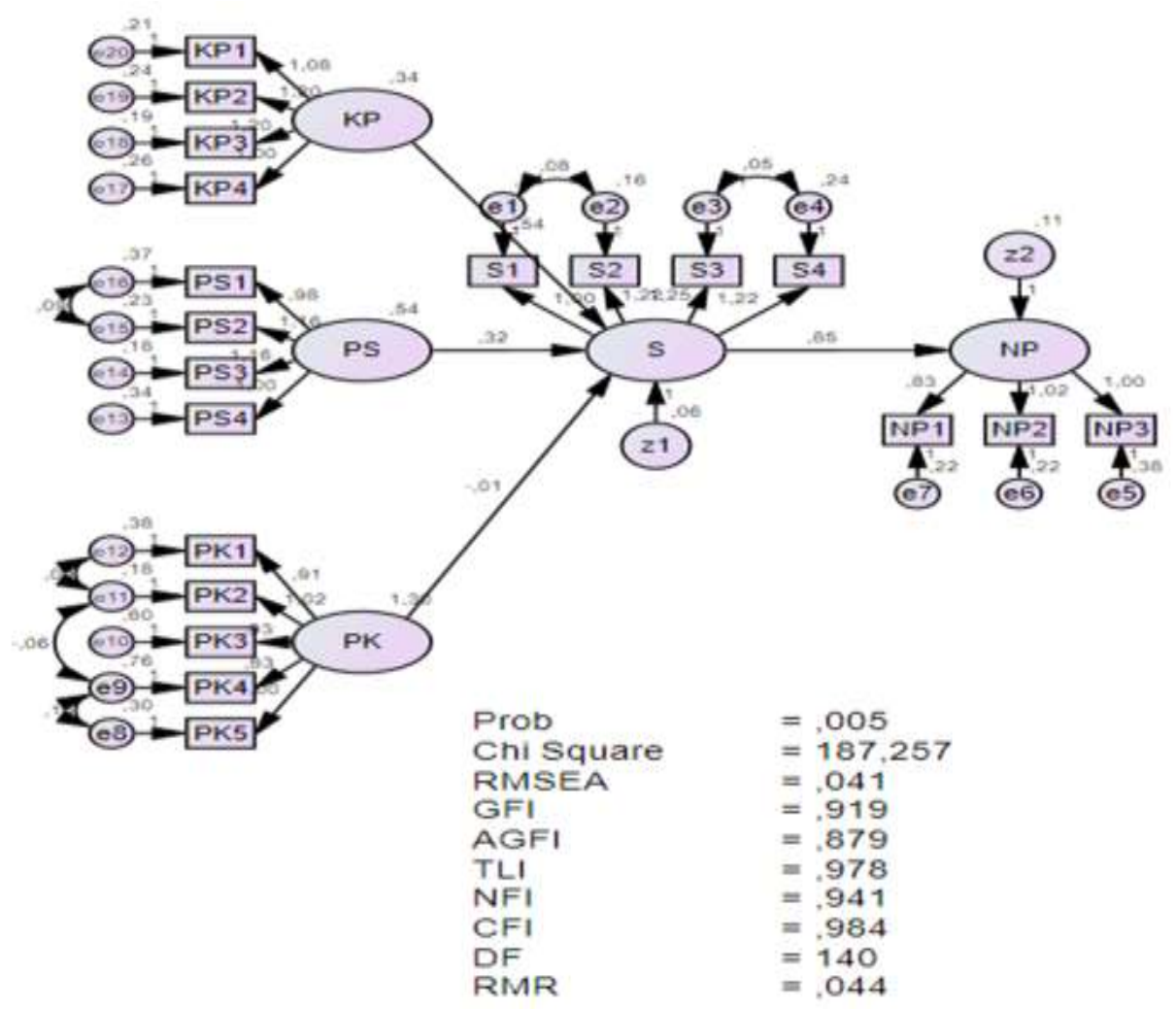

Gambar 2. Hasil Uji Hipotesis

\section{E. PEMBAHASAN}

Pengujian hipotesis dalam peneltian ini menemukan bahwa sikap berpengaruh positif terhadap niat perilaku untuk menggunakan layanan aplikasi kesehatan Grab Health selama masa pandemik Covid19, sehingga $\mathrm{H} 1$ terdukung. Hasil ini didukung oleh studi Faham dan Asghari (2019) yang menjelaskan bahwa sikap terhadap kualitias konten dalam aplikasi memeiliki efek sangat tinggi terhadap niat perilaku. Hal ini dikarenakan sikap positif dari individu akan menciptakan persepsi yang baik tentang kegunaan aplikasi (Faham \& Asghari, 2019). Studi lain juga menjelaskan bahwa sikap mampu memprediksi niat perilaku individu dalam menggunakan teknologi dengan melihat frekuensi dan durasi penggunaan apliaksi online (Rehman dan Shaikh, 2020).

Hasil uji hipotesis dalam penelitian ini menemukan bahwa ada signifikansi antara kenyamanan persepsian terhadap sikap dalam menggunakan layanan aplikasi kesehatan Grab Health, sehingga $\mathrm{H} 2$ terdukung. pencapian hasil yang bagus dalam aplikasi game online akan memengaruhi kondisi emosi indvidu dan memberikan tingkat kegembiraan yang tinggi. Dapat disimpulkan kenyamanan yang dipersepsikan memiliki pengaruh besar pada sikap individu dan frekuensi penggunaan 
dalam aplikasi game online (Alzahrani et al., 2017). Hasil ini juga didukung oleh studi Zhang et al. (2018) yang menejlaskan bahwa sikap positif dari individu untuk menggunakan suatu layanan aplikasi bukan hanya dipengaruh oleh fitur fungsional dari aplikasi, tetapi juga reaksi emosional atau kenyamanan individu (Zhang et al., 2018).

Hasil uji hipotesis dalam penelitian ini menemukan bahwa adanya signifikansi antara pengaruh sosial terhadap sikap dalam menggunakan layanan aplikasi kesehatan Grab Health selama masa pandemic Covid19 , sehingga H3 terdukung. Pengaruh sosial terhadap sikap pada budaya kolektivisme seperti Meksiko lebih tinggi dibandingkan negara dengan budaya individualisme seperti Spanyol (Jimenez dan Martin, 2017). Pengguna jejaring sosial online yang memiliki hubungan dekat dengan individu lain seperti teman atau keluarga sangat memiliki pengaruh yang besar untuk memengaruhi meraka menggunakan sebuah aplikasi, dibandingkan dengan pengguna lain yang sama sekali tidak memiliki hubungan karena adanya rekomendasi (Verkijika dan De Wet., 2018; Vahdat et al., 2020).

Hasil uji hipotesis dalam penelitian ini menemukan bahwa tidak adanya signifikansi antara kerentanan persepsian terhadap sikap dalam menggunakan layanan aplikasi kesehatan Grab Health, sehingga H4 tidak terdukung. Dari hasil tersebut dapat dijelaskan bahwa pengaruh kerentanan persepsian tidak memengaruhi sikap, jika individu tetap mempersepsikan positif layanan aplikasi tersebut aman dari berbagai risiko atau ancaman. Hasil ini berbeda dengan penelitian-penelitian sebelumnya Salleh et al. (2012), Guo et al. (2015), AlSaqar dan Seliaman (2016), dan Zhao et al. (2018) yang menyatakan bahwa kerentanan persepsian berpengaruh positif terhadap sikap individu. Kondisi ini bisa terjadi dikarenakan kondisi saat pada masa pandemi Covid-19, aplikasi layanan kesehatan online cenderung dibutuhkan oleh masyarakat dibandingkan mendapatkan layanan fisik di klinik maupun di rumah sakit. Masyarakat cenderung mengabaikan kekhawatiran terhadap adanya risiko penipuan dan penyalahgunaan informasi privasi dari Grab Health yang dianggap memiliki kredibilitas. Aplikasi kesehatan Grab Health dipersepsikan oleh masyarakat aman, nyaman, dan bermanfaat pada masa pandemik Covid-19 untuk melakukan konsultasi kesehatan yang bisa diakses dari mana saja tanpa harus keluar rumah.

\section{F. KESIMPULAN}

Studi ini dilakukan untuk menguji faktor-faktor yang dapat memengaruhi penggunaan layanan aplikasi kesehatan Grab Health selama pandemik Covid-19. Niat perilaku individu untuk menggunakan suatu layanan apliaksi kesehatan Grab Health dipengaruhi sikap individu yang disebabkan oleh kenyamanan yang dipersepsiakan individu, pengaruh sosial, 
dan kerentanan yang dipersepsikan. Hasil analisis data dalam studi ini menunjukkan $\mathrm{H}_{1}$, $\mathrm{H} 2$ dan $\mathrm{H} 3$ terdukung sedangkan $\mathrm{H} 4$ tidak terdukung. Hasil ini menunjukkan bahwa sikap positif masyarakat dalam membentuk niat menggunakan aplikasi Grab Health disebabkan adanya pengaruh lingkungan sosial disekitarnya, kenyamanan penggunaan dari aplikasi tersebut, dan mengabaikan adanya kerentanan dari aplikasi berupa resiko kehilangan privasi.

\section{KETERBATASAN PENELITIAN}

Penelitian hanya dilakukan pada satu objke penelitian saja yaitu aplikasi kesehatan Grab Health. Sehingga penelitian ini belum menunjukan generalisasi yang lebih luas dalam bidang aplikasi yang memberikan dan menyediakan layanan konsultasi, edukasi, informasi tentang kesehatan secara online. Penelitian ini juga dalam menguji niat perilaku pengguna hanya terbatas menggunakan empat variable saja yang sudah relative sering digunakan dan hanya menganalisis sikap pengguna sampai pada niat perilaku.

\section{IMPLIKASI MANAJERIAL}

Pengelola aplikasi kesehatan Grab Health perlu meningkatakn kredibilitas aplikasi dengan mencantumkan izin penjualan obat dan sertifikasi dokter yaitu Surat Izin Praktek (SIP) yang masih aktif dan tercatat secara resmi sevagai anggota Ikatan Dokter Indonesia (IDI), Menyediakan informasi, layanan konsultasi, edukasi dan ruang diskusi yang terpercaya, akuran, dan terlengkap bagi para pengguna dengan menjaga hubungan kerjasama dengan Ikatan Dokter Indonesia (IDI), dan Memberikan informasi yang jelas tentang peraturan dan kebijakan bagi pengguna tentang perlindungan informasi privasi pasien yang rentan disalahgunakan oleh pihak-pihak yang tidak bertanggungjawab.

\section{REFERENSI}

Alshehri M.m Drew S., Alhussain T., Alghamdi R. (2012). The Effects of Website Quality on Adoption of EGovernment Service: An Empirical Study Applying UTAUT Model Using SEM. Australasian Conference On Information System, pp. 1-13.

Adger W.N \& Kelly P.M. (1999). Social

Vulnerability to Climate Change and the Architecture of Entitlements.

Mitigation and Adaptation Strategies for Global Change, Vol. 4, pp. 253266.

Alzahrani A.I., Mahmud I., Ramayah T., Alfarraj O., Alalwan, N. (2017). Extending the Theory of Planned Behavior (TPB) to Explain Online Game Playing Among Malaysian Undergraduate Students. Telematics and informatics, Vol. 34, pp. 239-251. Al-Saqer N.S. \& Seliaman M.E. (2016). The Impact of Privacy Concerns and Perceived Vulnerability to Risks on 


\section{Vol-13/No-2/Oktober/2020}

Users Privacy Protection Behaviors on SNS: A Structural Equation Model. (IJACSA) International Journal of Advanced Computer Science and Applications, Vol. 7, No. 5, pp. 142-147.

Boonsiritomachai W. \& Pitchayadejanat K. (2017). Determinants Affecting Mobile Banking Adoption by Generation $Y$ Based on the Unified Theory of Acceptance and Use of Technology Model Modified by the Technology Acceptance Model Concept. Kasetsart journal of Social Sciences, Ed. November, pp. 1-10.

Choi J. \& Kim S. (2016). Is he Smartwatch an IT Product or a Fashion Product? A Study on Factors Affecting the Intention to Use Smartwatches. Computers in Human Behavior, Vol. 63, pp. 777-786.

Cabada R.Z., Estrada M.LB., Harnandes F.G., Bustillos R.O., Gracia C.A.R. (2018). An Affective and Web 3.0Based Learning Enivornment for a Programing Language. Telematics and Informatics, Vol. 35, No. 3, pp. 611-628.

Chaterine N., Geofrey K.M., Moya M.B., Aballo, G. (2017). Effort Expectancy, Performance Expectancy, Social Influence and Facilitating Conditions as Predictors of Behavior Intention to use ATMS with Fingerprint Authentication in Ugandan Banks.
Global Journal of Computers Science and Technology: E-Network, Web \&Scurity, Vol. 17, No. 5, pp. 5-22.

Chang S.E., Liu A.Y., Shen W.C. (2017). User Trust in Social Networking Services: A Comparison of Facebook and Linkedln. Computers in Human Behavior. doi: 10.1016/ j.chb.2016.12.013.

Faham E. \& Asghari H. (2019). Determinantsofbehavioralintentionto usee-textbooks:AstudyinIran's agriculturalsector. Computers and Electronics in Algiculture, Vol. 165, pp. 1-10.

Guo X., Han X., Zhang X., Dang Y., Chen, C. (2015). Investigating m-Health Acceptance from a Protection Motivation Theory Perspective: Gender and Age Differences. Telemedicine and e-Health, Vol. 21, No. 8, pp. 661-669. doi: 10.1089/tmj.2014.0166.

Hosaain A., Quaresma R., Rahman, H. (2019). Investigating Factors Influencing the Physicians' Adoption of Electronic Health Record (EHR) in Healthcare System of Bangladesh: An Empirical Study. International Juornal of Information Management, Vol. 44, pp. 76-87. doi.org/10.1016/j.jijinformgt.2018.09. 016.

Hamari J. \& Koivisto J. (2015). Why do People Use Gamification Services?. 
International Journal of Information Management, Vol. 35, pp. 419-431. doi.org/10.1016/j.ijinformgt.2015.04. 006

Ifinedo P. (2012). Understanding Information Systems Security Policy Compliance: An Intergration of thr Theory of Planned Behavior and the Protection Motivation Theory. Computers \& Security, Vol. 31, pp. 83-95. doi: 10.1016/j.cose.2011.10.007.

Johnston A.C. \& Warketin M. (2010). Fear Appeals and Information Security Behaviors: An Empirical Study. MIS Quarterly, Vol. 34, No. 3, pp. 549566.

Jimenez N. \& Martin S.S. (2017). Attitude Toward m-Advertising and mRepurchase. European Research, Vol. 23, pp. 96-102. doi.org/10.1016/j.iedeen.2016.12.00 $12444-8834$.

Kuo Y.F. \& Yen S.N. (2009). Towards an Understanding of the Behavioral Intention to Use 3G Mobile ValueAdded Services. Computers in Human Behavior, Vol. 25, pp. 103110. doi:10.1016/j.chb.2009.07.007.

Liaw S.S. \& Huang H.M. (2003). An Investigation of User Attitudes Toward Search Engines as an Information Retrieval Tool. Computers in Human Behavioral, Vol. 19, pp. 751-765.
Lin F., Fofanah S.S., Liang, D. (2011). Assessing Citizen Adoption of eGoverment Intiatives in Gambia: A Validation of the Technology Acceptance Model in Infomation System Success. Government Information Quarterly, Vol. 28, pp. 271-279.

Lam T., Cho V., Qu, H. (2007). A Study of Hotel Employee Behavioral Intentions Towards Adoption of Information Technology. Hospitality Management, Vol. 26, pp. 49-65.

Mobley W., Horner S., Hollingsworth A. (1978). An Evaluation of Precursos of Hospital Employee Turnover. Journal of Applied psychology, Vol. 63, No. 4, pp. 408-414.

Minha J.R.A., Gapar Md., Johar Md., Alkawaz M.H. (2018). The Influence of Perceived Confidentiality Risks and Attitude on Tanzania Government Employees' Intention to Adopt Web 2.0 and Social Media for Work-Related Purposes. International Journal of Public Administration, pp. 1-14. doi: 10.1080/01900692.2018.1491596.

Mohamed N. \& Ahmad I.H. (2012). Information Privacy Concerns, Antecedents and Privacy Measure Use in Social Networking Sites: Evidence from Malaysia. Computers in Human Behavior, Vol. 28, pp. 


\section{Vol-13/No-2/Oktober/2020}

2366-2375.

doi:

10.1016/j.chb.2012.07.008.

Nasri W. \& Charfeddine L. (2012). Factors Affecting the Adoption of Internet Banking in Tunisia: An Intergration Theory of Acceptance Model and Theory of Planned Behavior. Journal of High Technology Management Research, Vol. 23, pp. 1-14. doi:10.1016/j.hitech.2012.03.001.

Ojo A.O., Raman M., Downe A.G. (2019). Toward Green Computing Practices: A Malaysian Study of Green Belief and Attitude among Information Technology Professionals. Journal of Cleaner Production, Vol. 224, pp. 246-255.

doi:

10.1016/j.clepro.2019.03.237.

Preevena K. \& Thomas S. (2014). Continuance Intention to Use Facebook: A Study of Perceived Enjoyment and TAM. Bonfring International Journal of Industrial Engineering and Management Science, Vol 4, No. 1.

Rana N.P., Dwivedi Y.K., Williams M.D., Weerakkody, V. (2016). Adoption of Online Public Grievance Redressal System in India: Toward Developing a Unified View. Computers in Human Behavior, Vol. 59. Pp. 262-282. doi: 10.1016/j.chb.2016.02.019

Rana N., Dwivedi Y., Lal, B. (2015). Factor Influencing Citizen's Adoption of an
E-Goverment System: Validation of the Decomposed Theory of Planned

Behavior. UK Academy for Information System Conference Proceedings. Vol. 14.

Rehman Z.U. \& Shaikh F.A. (2020). Critical Factors Influencing the Behavioral Intention of Consumers towards Mobile Banking in Malaysia. Engineering, Technology \& Applied Science Research, Vol, 10, No. 1, pp. 5265-5269.

Serenko A. \& Turel O. (2015). Intergrating Technology Addiction and Use: An Empirical Investigation of Facebook Users. Transactions on Replication Research, Vol. 1, No.2, pp. 1-18.

Scanlan T.K. \& Lewthwaite R. (1986). Social Psychological Aspects of Competition for Male Youth Sport Participants: IV. Predictor of Enjoyment. Journal of Sport Psychology, Vol. 8, pp. 25-335.

Siponen M., Mahmood M.A., Pahnila S. (2014). Employees' Adherence to Information Security Policies: An Exploratory Field Study. Information \& Management, Vol. 51, pp. 217-224. doi: 10.1016/j.im.2013.08.006.

Salleh N., Hussein R., Mohamed N., Karim N.S.A., Ahlan A.R., Aditiawarman, U. (2012). Examining Information Disclosure Behavior on Social Network Sites Using Protection 
Motivation Theory, Trust and Risk. Journal of Internet Social Networking \& Virtual Communities, Vol. 2012, pp.

1-11. doi: 10.5171/2012.281869.

Tharhini A., Scott M., Sharma S., Abassi, M. (2015). Differences in Intention to Use Educational RSS Feeds BetweenLebanese and British Students: A Multi-Group Analysis Based on the Technology Acceptance Model. The Electronic Journal of e-Learning, Vol. 13, No. 1 , pp. 14-29.

Venkatesh V. (2000). Deteminants of Perceived Ease of Use: Integrating Control, Intrinsic Motivation, and Emotion into the Technology Acceptance Model. Information Systems Research, Vol. 11, No. 4, pp. 342-365.

Vankatesh V., Thong J., Xu, X. (2012). Consumer Acceptance and use of Information Technology: Extending the Unified Theory of Acceptance and use of Technology. Management Information System Quarterly, Vol. 36, No. 1, pp. 157-178.

Verkijika S.F. \& Wet L.D. (2018). Egovernment Adoption in subSaharan Afric. Electronic Commerce Research and Applications, Vol. 30, pp. 83-93. doi.org/10.1016/j.elerap.2018.05.
Vahdat A., Alizadeh A., Quach S., Hamelin N. (2020). Would You Like to Shop Via Mobile App Technologi? The Technologi Acceptance Model, Social Factors and Purches Intention. Australian Marketing Journal, pp. 1-10.

Yusliza M.Y. \& Ramayah T. (2012). Determinants of Attitude Towards EHRM: An Empirical Study among HR Professionals. Procedia - Social and Behavioral Sciences, Vol. 57, pp. 312 - $319 . \quad$ doi: 10.1016/j.sbspro.2012.09.1191.

Zhang J., Liu B., Tang J., Chen T., Li, J. (2013). Social Influence Locality for Modeling Retweeting Behaviors. Computer Science and Technology. Pp. 2761-2767

Zhang T., Lu C., Kizildag M. (2018). Banking "on-the-go":Examining Consumers' Adoption of Mobile Banking Services. International Journal of Quality and Service Sciences. doi. doi.org/10.1108/IJQSS-07-20170067.

Zhao Y., Ni Q., Zhou R. (2018). What Factors Influence the Mobile Health Service Adoption? A Meta-Analysis and the Moderating Role of Age. International Journal of Information Management, Vol. 43, pp. 342-350. doi.org/10.1016/j.ijinformgt.2017.08. 006. 